\title{
THE ROLE OF LIVING GREEN WALL IN POWER MANAGEMENT IN BIG CITIES
}

\author{
Farnaz Ghadiri Garakani \\ Payame Noor University, Tehran, Iran
}

\begin{abstract}
Green walls reduce the air temperature and cause the thermal insulation of the walls and reduce the absorption of solar energy and the reflected rays from streets and other buildings in the city makes the heat island phenomenon due to urban life to be modified on a considerable extent. All the items listed lead to energy management and reduce costs in terms of maintenance and control at the time of productivity. Green walls work with water recirculation system and by absorbing the non-water-soluble nutrients which are the mineral bacteria are used to reduce water pollution. This study examines the types of green walls and their performance in energy saving and investigated its role in energy management and studies the solutions. Since the thermal resistance of the wall depends on thermal conductivity or the conductivity of the constituent layers and conductivity of the air film layers surrounding the internal and external surfaces, layers of vegetation on frontage have considerable effect to improve the strength of the wall and its thermal performance and saving energy consumption in all the seasons.
\end{abstract}

Keywords: Living green wall, energy management, big cities, planning

\section{BÜYÜK ŞEHIRDE GÜÇ YÖNETIMI VE YEŞIL YAŞAM DUVARININ ROLÜ}

\section{ÖZ}

Yeşil duvarlar hava sıcaklığını düşürmek ve duvarların 1sı yalıtımı şehirlerde önemli ölçüde modifiye olması nedeniyle kent yaşamına 1S1 adası fenomen yapar ve güneş enerjisi emilimini ve sokakların ve diğer binalardan yansıyan 1şınları azaltır. Listelenen tüm öğelerden dolayı enerji yönetiminin yol ve verimlilik bakımından ve kontrolü açısından maliyetlerini azaltmak zorunludur. Yeşil duvarlar, su sirkülasyon sistemi ve bakteri su kirliliğini azaltmak için kullanılan mineral suyla çözülebilir. Bu çalışma, yeşil duvar türlerini ve enerji tasarrufu performanslarını incelemekte ve enerji yönetimi rolünü araştırarak çözümler aramaktadır. Duvarın 1sı direnci, termal iletkenliği veya bileşen tabakalar, iç ve dış yüzeyleri çevreleyen hava filmi tabakanın iletkenliği iletkenliğine bağlı olduğu için, ön tarafa bitki örtüsü tabakalarının duvarı ile termal dayanıklılığını geliştirmek için önemli bir etkiye sahip her mevsim performans ve enerji tasarrufu tüketimi.

Anahtar Kelimeler: Yaşayan Yeşil duvar, enerji yönetimi, büyük şehirler, planlama

\section{INTRODUCTION}

Green wall, green façade, vertical gardens, hanging gardens, living wall, biological wall, etc. are several technologies which have a special place in the areas of energy management and the environment and a lot of them can be found in various references. This technology in environmentally, terms of energy saving, economy, social issues, psychology, recreational opportunities, preventing the emission of greenhouse gases, preventing heat islands, improving the air and water quality, providing habitat for many organisms, food production, job creation, and aesthetic aspects has found wide applications and substantial benefits. 
Some of these concepts have been used and considered in the Hanging Gardens of Babylon in the sixth century BC. The creation of green surfaces in dry hot days in cities like Tehran can be effective in ventilation and cool urban environment. (4)

According to the Ministry of Housing and Urban Development Studies (Green Book, Volume 9), the conventional and acceptable per capita green spaces in cities in Iran is 7 to 12 square meters per person which compared with the index set by the United Nations environment (20 to 25 square meters per person), is lower. However, in different cities this figure due to the different geographical and climatic characteristics of them along with the differences that determine the amount of each of the towns it passed through. However, due to the high value of land in our country and vertical growth of cities and urbanization, less urban green space is created; therefore, the use of the green walls technology which is an advanced technique of green space, despite the difficulties in implementing and building, is very affordable in many ways and it can be a good alternative for urban parks. (5)

\section{ADVANTAGES OF GREEN WALLS}

Advantages of green walls is not only limited to the beauty, these walls act as insulation that helps to regulate interior space. It is observed that the outer surface of a wall that is attached to the green wall is 10 degrees cooler than the temperature of a wall exposed to the air. With rising costs and lack of energy, this green wall reduces energy consumption in cooling or heating of energy.

These structures have the ability to reduce up to $20 \%$ of the electricity bill. The existence of building causes protection against sunlight, rain, snow and thermal fluctuations. Other advantages of green walls include the ability to re-use the water. Plants re-use water by breaking down foods and nutrients in it. As well, they have the ability to absorb noise and reducing noise pollution inside the building.

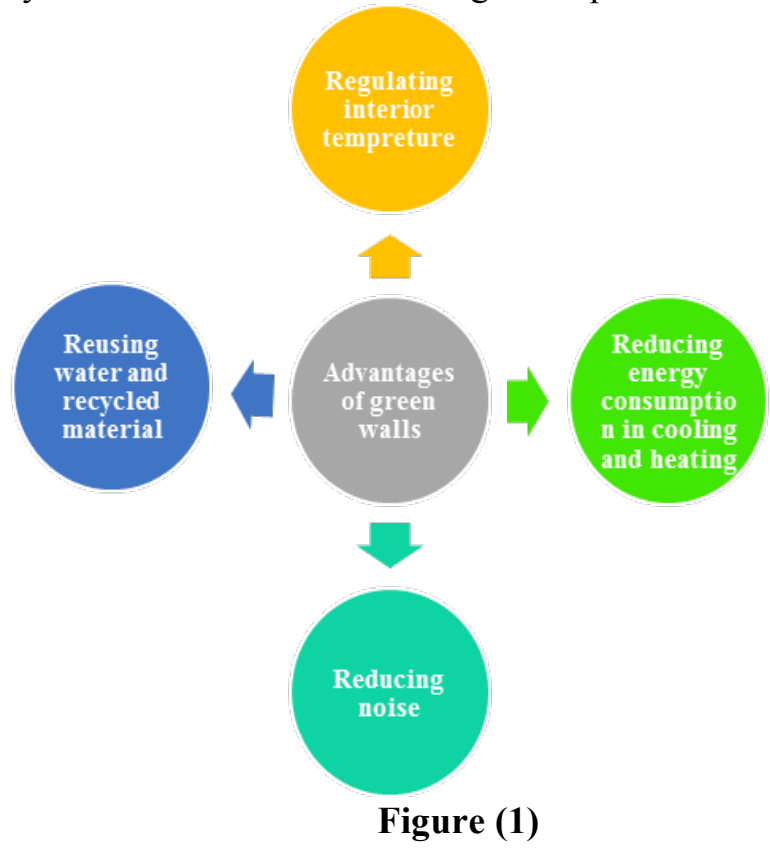

\section{A VARIETY OF GREEN WALLS:}

Although green roof systems follow almost a similar trends, but in green walls, there are many differences between systems. Therefore, it is necessary to determine a classification of green walls to know their types and comparing their behavior as passive energy storage systems in the future. The first classification can be based on green facades and Living Walls. (5) 


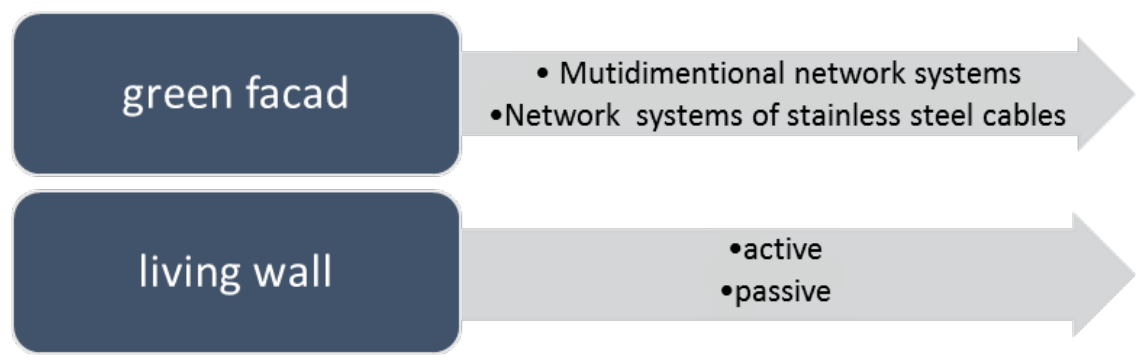

Figure (2)

\section{GREEN FACE}

Green plant moves in frames on the facade where ivy grows on the facade rooted in the ground or on a bed of soil. In many cases structural support for green facades is also considered. The structures or networks is connected to the wall or is run as panel. These views are a type of green wall where a variety of climbing plants or cascade short plants are used for preservative structures such as modular panel system network or systems of wire ropes and cables. (1)

In this system, plants are planted at the base of these structures or in the garden with different levels. It takes several years to reach full growth. Green features of this group are divided into two categories:

- $\quad$ A multi-dimensional grid system of welded systems.

- $\quad$ network of cable systems made of stainless steel (2)

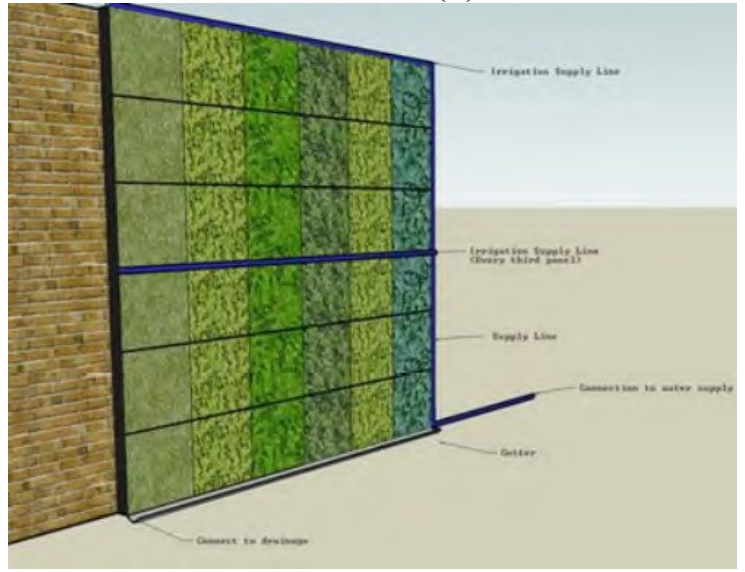

Figure 1: network layer (6)

\section{ACTIVE SYSTEMS OF LIVING WALL:}

These systems are the newest type of green walls. The system uses the air produced by the plant in building air conditioning systems. Green walls increase air purification capacity with biological filter. Plants root in the area between two layers of fibrous materials which are embedded in the wall. Water drops between layers and feeds the moss, vines and other plants. Bacteria on the root cause deformation of air impurities such as volatile organic compounds. The active are walls connected to the air circulation system of the building. Fan draws air through the wall and the air is then positioned in the building. (3). The living green walls have very good application in large cities like Tehran for energy and economic savings. As well a system can be used to run which is composed of all the recycled components and the uses of human resources all help manage energy. (5). Among a variety of green walls, the best type to save and manage energy is a kind of living wall being more affordable in terms of cost and application. 


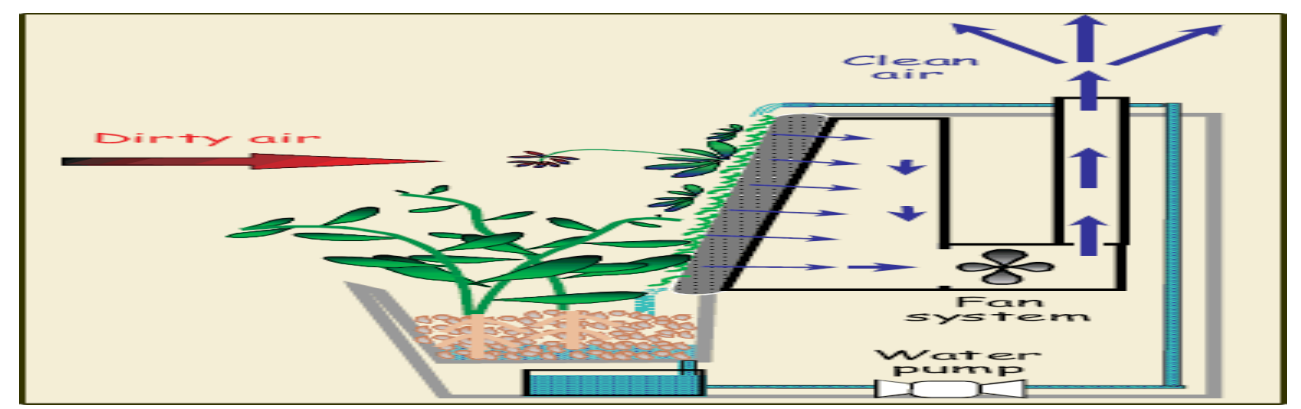

Figure 2: living wall functioning with the help of water reuse (5)

\section{APPLICATION IN BIG CITIES}

Active living wall is one of the newest types of green walls which is designed with the integration of Heating / Cooling facilities and ventilation of the building so that it filters the indoor environmental air and acts as a thermal regulator. In this system, the air generated by plants is used for air conditioning in the building; herb absorb the monoxide and carbon dioxide and removes the cultivars of the root, organic compounds and particulate matter in the air and the plant natural process produces fresh air which is drawn through a vent in the system and is then distributed indoor. The root system is placed between two layers of industrial textiles and cultivation system is hydroponic and their feed is done through the water rich with nutrients. (2)

\section{ENVIRONMENTAL ADVANTAGES OF LIVING GREEN WALL}

Modifying the air quality and thereby reducing carbon pollution:

Roofs and green walls purify air and produce oxygen by absorbing carbon dioxide. Only 5 square meters of green grass, provides enough annual oxygen for a person.

\section{ACOUSTIC INSULATION:}

Roofs and green walls lined with plants and soil can be considered as acoustic insulation for buildings (1).

\section{REDUCE THE HEAT ISLAND EFFECT OF CITIES:}

The system can create effective ways to reduce greenhouse gas emissions by providing shade in the buildings and improving insulation of the building and reducing the urban high temperatures that are created by the expansion of reflective surfaces in urban areas and are known as the urban heat island effect. Concrete surfaces such as asphalt and concrete in urban areas in buildings absorb the heat during the day and then at night return it back to the atmosphere. This phenomenon creates the heat island effect by heat released in the evening and forming a dome of high temperatures across the city. The heat island adds to global warming. Green walls can help to reduce the environmental impact only about 6 percent of urban green walls can take temperature 1 to 2 degrees lower. (1)

\section{ECONOMIC ADVANTAGES OF THE LIVING GREEN WALLS:}

- $\quad$ Expanding the industry of the green walls construction can have a huge economic impact. This technology can create new jobs in construction, manufacturing and designing and also installation and other services. In addition, these systems have other benefits as well.

- $\quad$ Building insulation in winter and summer and low power consumption, extend the life of about 2 to 3 times the wall of the building temperature control and MAC latest energy costs and extend the life of the building. (4)

Aesthetic advantages of the living green walls:

- Reconstruction and revitalization of our cities must be compatible external architecture that meets the aspirations of different communities.

- Visual comfort: with the addition of this technology, green urban spaces create the possibility of creating urban communities and indigenous sustainable natural and relaxing there. 
- Diversity in design: green walls can be designed in various forms and can be used on different partitions. (4)

\section{THE ROLE OF GREEN WALLS IN ENERGY MANAGEMENT:}

Green walls by modifying the heat island and low-cost purification of ambient air and ensure human health and the reduction of municipal wastewater. With a succession of green wall instead of the usual walls of the problems caused by the effects of heat islands and reduced the problems of demanding more energy. Further, green walls reduce the amount of waste and dangerous caused by pollution. Green walls are also the perfect solution to solve the ecological problems in cities and metropolitan centers and fix human health and the environment problems. (3) Green walls with positive effects such as reducing the need for cooling in summer and heating in the winter and reducing energy building surface temperature of the surrounding environment, creating heat and cold cuts wind, long-term protection of the building shell, considering aesthetic issues and providing appropriate plant species to ecosystems can play an important role in sustainable architecture and urbanism and management of building energy dosage.

\section{CONCLUSION}

In this context, the use of recycled materials and native plant species for weight and heavy, costs and warranties and incentive for projects, etc. can help to create the right and more efficient combination.
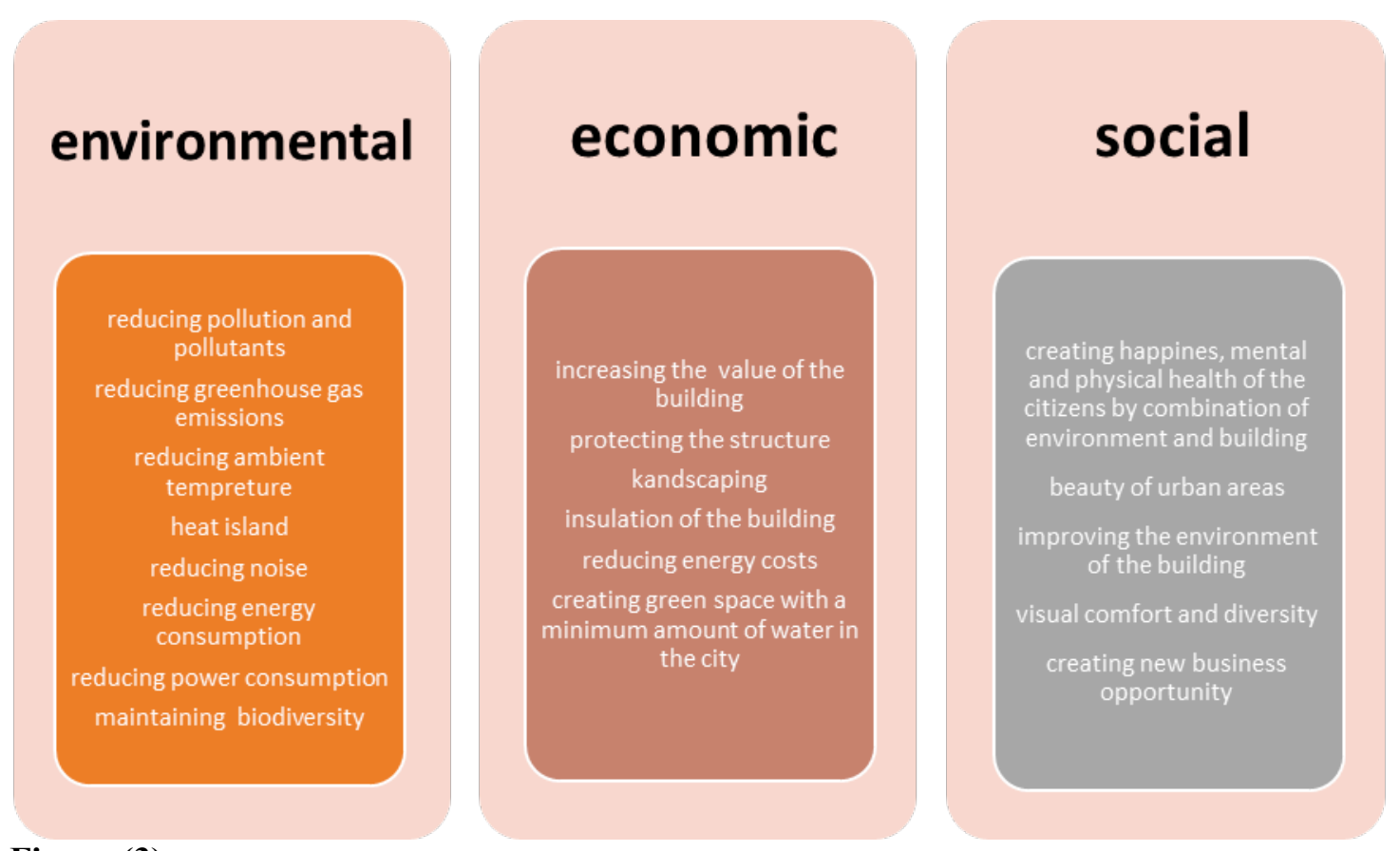

Figure (3)

\section{REFERENCE}

1. ABC of green-building approach to sustainability by David Wright, Translation: Vahid Schally, Parham Amini Naghsh Publication

2. Book in Iran's energy planning with an emphasis on green buildings, Shahin Heidary, Tehran University Press, 2009 
3. Green architecture with advanced materials and technology, Osman Athman, Translator: Sarah Azhari, Mehrazan Publication, 2011

4. Green building, micheal bauer, peter mosle, micheal swchward

5. The impact of radiation on the green wall in buildings, Zahra Qyabklou, Shahid Beheshti University Press, 2003

6. Theoretical principles and implementation of energy use in green buildings, Donald Watson and Kenneth Lab , Translation: Vahid Qbadyan, Tehran University Press 